HUNGARIAN AGRICULTURAL ENGINEERING

$N^{\circ} 26 / 2014$ 32-38

Published online: http://hae-journals.org/

HU ISSN 0864-7410 (Print) / HU ISSN 2415-9751(Online)

DOI: 10.17676/HAE.2014.26.32
PERIODICAL OF THE COMITTEE OF AGRICULTURAL AND BIOSYSTEM ENGINEERING OF THE HUNGARIAN ACADEMY OF SCIENCES and SZENT ISTVÁN UNIVERSITY

Faculty of Mechanical Engineering

\title{
WATER MANAGEMENT IN MIDDLE EAST AND NORTH AFRICA
}

\author{
Author(s): \\ J. S. Zsarnóczai, Bahaa Asma, A. Vajda
}

Affiliation:

Szent István University, Faculty of Economic and Social Sciences, Institute of Regional Economics and Rural Development, 2103 Gödöllő, Páter Károly utca 1., Hungary

Email address:

zsarnoczai.sandor@gtk.szie.hu, kekk@gtk.szie.hu, vajdandi@gmail.com

\begin{abstract}
In Middle East and North Africa (MENA) the natural water supply is very important for water consumption of population and the agricultural sector. The total available freshwater in MENA region is 467 billion $\mathrm{m} 3(\mathrm{~km} 3)$ of which $81,8 \%$ is for only Middle East, and of which $70 \%$ is only for two countries, namely Turkey and Iran. The remaining $30 \%$ is availability for the Arab countries in Middle East $(11,8 \%)$ and North Africa $(18,2 \%)$. Also the other unfavourable issue for the MENA region (without Turkey), that only $22,7 \%$ of all available water is groundwater. The large portion of the surface water results in serious difficulties, because of the warm dry weather the water evaporation is very considerable.

The Great Man-Made River (GMR) Project would yield five times more water cost effectively than the earlier traditional water resource options before 1983. The Great Man-Made River Authority was created and invested with the responsibility of taking water from the aquifers in the south, and conveying it by the most economical and practical means for use, predominantly for irrigation, in the Libyan coastal belt.

These natural conditions show how the water use for irrigation has mainly been concentrating on two smaller regions of MENA, namely Nile river and cultivable agricultural fields between Euphrates and Tiger rivers as it has been called Mesopotamia for several thousands of years. The concentrated irrigated lands did not help to extend the improved technologies for irrigation; therefore the other sub-sectors of the agriculture cannot be developed, for example animal husbandry and plan production. The possible development trend of the technology and techniques can be solved by improving the renewable natural resource use from water, wind and solar energy within the sustainable investment; also we do not forget the salinization of sea water to make it be satisfactory drinking for population of these regions.
\end{abstract}

\section{Keywords}

Water supply, Groundwater, Surface water, Grate Man-Made River Project

\section{Introduction}

The study uses wide-side international scientific literatures and statistical data given by the international special organizations, the regional one and national institutions specialised in water use and irrigation. The total available freshwater in MENA region is 467 billion $\mathrm{m} 3(\mathrm{~km} 3)$ of which $81,8 \%$ is for only Middle East, and of which $70 \%$ is only for two countries, namely Turkey and Iran. The remaining $30 \%$ is availability for the Arab countries in Middle East $(11,8 \%)$ and North Africa $(18,2 \%)$. Also there is a significant difficulty, namely the soil degradation is mainly resulted by wind in North Africa, which needs forestry settlement (Yahia Ali Mughram - Zsarnóczai, 2008).

The social-economic demands need improvement of water using technologies and also to widen the water using diversification in MENA region, for example in field of energy resource production and use from renewable natural resources, as most important one is the water. The growth of population needs much more food production and in consequence of which, water use within unfavourable dry weather conditions based on the global warming process (Ligetvári et al. 2006, 96-97. p.). Naturally the natural conditions for water use is not favourable in MENA region, because the drought period almost without raining is extending for more than half of the year, which tendency has been keeping for the last several centuries.

\section{Materials and Methods}

The study analyses the water management in Middle East and North Africa emphasizing the similarities and differences of water conditions and use in several countries of these regions based on the compare methods. The compare methods use mainly statistical data characterizing the special given natural conditions for using water resources in fields of water supply for the agricultural sector, mainly for irrigation. Based on the SWOT analyses the study would like to focus on backwardness of MENA, as two regions from the real demand level for the water use and also the possible diversified water uses.

In general the approximate annual evaporate-transpiration rate, which we can call as the loss of water to the air, is almost higher by two or 20 times more than the averagely rainfall per year in this region. Water can be lost by the evaporation from surface, plants produced by farmers. Also $22,7 \%$ of all available water is groundwater in the MENA region, which can make more difficulty for the water supply. The natural and climatic changes of these two regions, namely the Middle East and North Africa need special water uses and irrigation system meeting the social demands, natural conditions and technical developed levels in countries of these regions. 


\section{Results and discussion}

The Middle East and North Africa (MENA) region has very considerable difficulties concerning the environmental conditions, because, excluding Turkey, this region has 1.100 million hectare land where the humid zone is less than 10 percent of the region, the other $90 \%$ is dry or drier part of the region, where the $30 \%$ of population lives. Also the large scale irrigated areas are only $2 \%$ of this total area. The large scale irrigated area includes the Nile and Euphrates-Tiger river-valleys. While 20 million ha of land are irrigated, as $32 \%$ of 62,5 million hectare cultivated lands (FAO, No.33).

These natural conditions show how the water use for irrigation has mainly been concentrating on two smaller regions of MENA, namely in Nile river valley and cultivable agricultural fields between Euphrates and Tiger rivers as it has been called Mesopotamia for several thousands of years. The concentrated irrigated lands did not help to extend the improved technologies for irrigation; therefore the other sub-sectors of the agriculture can not be developed, for example animal husbandry and plan production. Therefore the technical backwardness could be more permanent, which led to the general backwardness for society of MENA region. Until now the developing trade of these regions and its possible incomes could not solve the wider future technical development and investments therefore the capital created by the even profitable trade should almost withdraw from these regions.

In 2000 the average yield of wheat was 1,4 ton per hectare. Comparably the average middle yield of wheat was 3 ton per hectare, and its good average yield was 6 ton per hectare in Hungary. In Middle East and North Africa region it often happens. Either forestry or cultivate plants production cannot decrease the wind influences for soil degradation, because the dry and warm climatic conditions cannot create adequate natural background for them. The other important difficulty is that the withdrawing groundwater in Libyan coastal, Nile Delta of Egypt and the Middle East's coastal areas. Because the water withdrawing is very intensive mainly for agriculture, in this case in 3-5 km distance from the coast the freshwater is reduced and the sea water intruded and took positions closer to the surface. Pumps started pumping the salt water into the place of earlier ground fresh water. Continuously the level of the sea water flowing into place of the earlier freshwater increases over the sea level near to the coast. In order to discontinue this problem under face cistern system should be set up.

The highland mixed farming system is extending mostly in this region, while and also this farming system is laying in MENA region, as much as about 75 million ha, which includes 8 percent of population in both of regions. The farmers cultivate 22 million hectare, of which 5 million hectare can only be irrigated. Based on this farming system the producers can get rained cereal, legume cropping, tree crops, fruits and olives in terraces with vines from their lands. Also they use grazing animal husbandry technology by livestock mainly sheep, which is very famous from Iran to Morocco (see detailed in Table-1).

In the climatic conditions of tropical areas, the aridisols are extensive and they are characterised by strong potential evaporation exceeding precipitation mainly during most of the year. The soils cannot be cropped without irrigation. They have low level of soil organic matters associating with the lack of vegetation, because of low rainfall, chemical reaction. By the hand aridisols are can be quite productive if they are irrigated, by the other hand they can be so much saline. The parse - arid farming system covers more than 60 percent of MENA region, which includes vast desert zones, and main soil is aridisols. About four million people lives within this farming system, as much about five percent of MENA region's agricultural population, who mainly lives in oases and in some of irrigation schemes of North Africa: from Morocco to Libya. 1,2 million hectare is irrigated and dates, other palms, fodder, vegetables are produced. Cattle, camels, sheep and goat are the famous for animal husbandry. Within this farming system grazing for the herds of pastoralists is going on (see in detailed in Norman et al, 1995).

Chart 1. Major Farming Systems of Middle East and North Africa Source: FAO data

\begin{tabular}{|l|c|c|l|l|}
\hline Farming Systems & $\begin{array}{c}\text { Land-Area } \\
\text { (\% of region) }\end{array}$ & $\begin{array}{l}\text { Agric. Population } \\
\text { (\% of region) }\end{array}$ & $\begin{array}{l}\text { Principal } \\
\text { Livelihoods }\end{array}$ & $\begin{array}{l}\text { Prevalence } \\
\text { of Poverty }\end{array}$ \\
\hline Irrigated & 2 & 17 & Fruits, vegetables cash crops & Moderate \\
\hline Highland Mixed & 7 & 30 & $\begin{array}{l}\text { Cereals, legumes, sheep, } \\
\text { off-farm work }\end{array}$ & Extensive \\
\hline Rainfed Mixed & 2 & 17 & $\begin{array}{l}\text { Tree crops, cereals, legumes, } \\
\text { off-farm work }\end{array}$ & $\begin{array}{l}\text { Moderate } \\
\text { (for small farmers) }\end{array}$ \\
\hline Dryland Mixed & 4 & 14 & $\begin{array}{l}\text { Cereals, sheep, } \\
\text { off-farm work }\end{array}$ & $\begin{array}{l}\text { Extensive } \\
\text { (for small farmers) }\end{array}$ \\
\hline Pastoral & 23 & 9 & $\begin{array}{l}\text { Sheep, goats, barley, } \\
\text { off-farm work }\end{array}$ & $\begin{array}{l}\text { Extensive } \\
\text { (for small herders) }\end{array}$ \\
\hline Sparse (Arid) & 62 & 5 & $\begin{array}{l}\text { Camels, sheep, } \\
\text { off-farm work }\end{array}$ & Limited \\
\hline Coastal Artisanal & -- & 1 & $\begin{array}{l}\text { Fishing, } \\
\text { off-farm work }\end{array}$ & Moderate \\
\hline Fishing & -- & 1 & $\begin{array}{l}\text { Fishing, } \\
\text { off-farm work }\end{array}$ & $\begin{array}{l}\text {-- } \\
\text { off-farm work }\end{array}$ \\
\hline Urban Based & $<1$ & 5 & & Limited \\
\hline
\end{tabular}

\section{In Libya}

The idea of the Great Man-Made River was mooted at the General People's Congress on 3rd October 1983. This followed geological revelations that up to $120.000 \mathrm{~km} 3$ of water lay beneath the Sahara Desert dating 14-38 000 years. It emerged that within a given budget, the Great Man-Made River (GMR) Project would yield five times more water cost effectively than the above three 
options combined in October 1983, the Great Man-Made River Authority was created and invested with the responsibility of taking water from the aquifers in the south, and conveying it by the most economical and practical means for use, predominantly for irrigation, in the Libyan coastal belt.

The phase I. of the project was commissioned in 1990, and completed in November 1994. The system is able to supply $2.000 .000 \mathrm{~m} 3$ of water per day to Benghazi, the second-largest city in Libya. The phase II. of the project finished in September 2000 , completed the water supply section for the main city of Tripoli. It brings 2,5 million tones of water to Tripoli. The phase III. will increase water flow in the Phase 1 system by 1.680 .000 $\mathrm{m} 3$ /day while phase IV. will provide $1.000 .000 \mathrm{~m} 3$ /day of water through a pipeline to Tobruk. Phase V. will connect Phases I. and II, and install two power stations to pump the $1.000 .000 \mathrm{~m} 3 /$ day of water. The Great Man - Made River aims at the mass transfer of waters from the Kufra and Sareer Basins beneath the earth surface to the coastal concentration of population in Benghazi, Sirte and Tripoli. Upon completion the huge network of pipelines will extend to about 4.000 kilometers and two aqueducts of some $1.000 \mathrm{~km}$. The project will carry more than 5 million $\mathrm{m} 3$ per day across the desert and increase the size of arable land from 327.000 hectares (1991) by 60.000 hectares (1992) and another 180.000 hectares in the second half of the decade (Huda Fathi Salem et al, 2005; The Large Farm, 2005).

The animal husbandry has considerably developed since the first units of GMR Project started their operation. The favourable situations were established for interest of increasing plant production and animal husbandry. The FAO declared some basic principles for growth of MENA regions within several international panels a round meetings, of which participants could declare that the GMR in Libya became one of the most successful investments of all of the developing countries, (UNDP/FAO, 2005):

- in the growth of the agricultural production based on the supports for farmers to buy agricultural machines, fertilisers, seeds with establishment of national sized advisory network to provide information for farmers and to build up the service network of machines;

- promote co-operation between farmers in fields of selling and buying in order to increase food-self sufficiency, decrease of food-import, also to establish family farm units.

The international organizations, like FAO and Arab League follow some main aims to be implemented in MENA regions, as follows:

- to follow the domestic market price system for agricultural and food products at low level for interest of domestic purchasing capacity and in the same time;

- to realise the governmental financial support, by the other name direct payment for farmers, as well.

According to previous plans, number of these water reservoirs is in south west of Benghazi, to a total capacity of 76 million $\mathrm{m}^{3}$, with further reservoirs in the Sirt area sized at 37 million $\mathrm{m}^{3}$. Other smaller reservoirs are constructed in Nuwfaliyah, Bishr and for the existing development projects at certain wadis. Upon completion of the Great Man Made River Project, about 155.000 hectares of fertile land will be cultivated and irrigated by the water from the project. The reclamation and development of some 38.000 hectares south of the Benghazi plain served by the Ajdabiya-Benghazi line, and some 18.000 hectares on the Ajdabiya-Sirt line, has already started, in addition to preparations for irrigation of the existing wadi developments (Pallas, 1980).

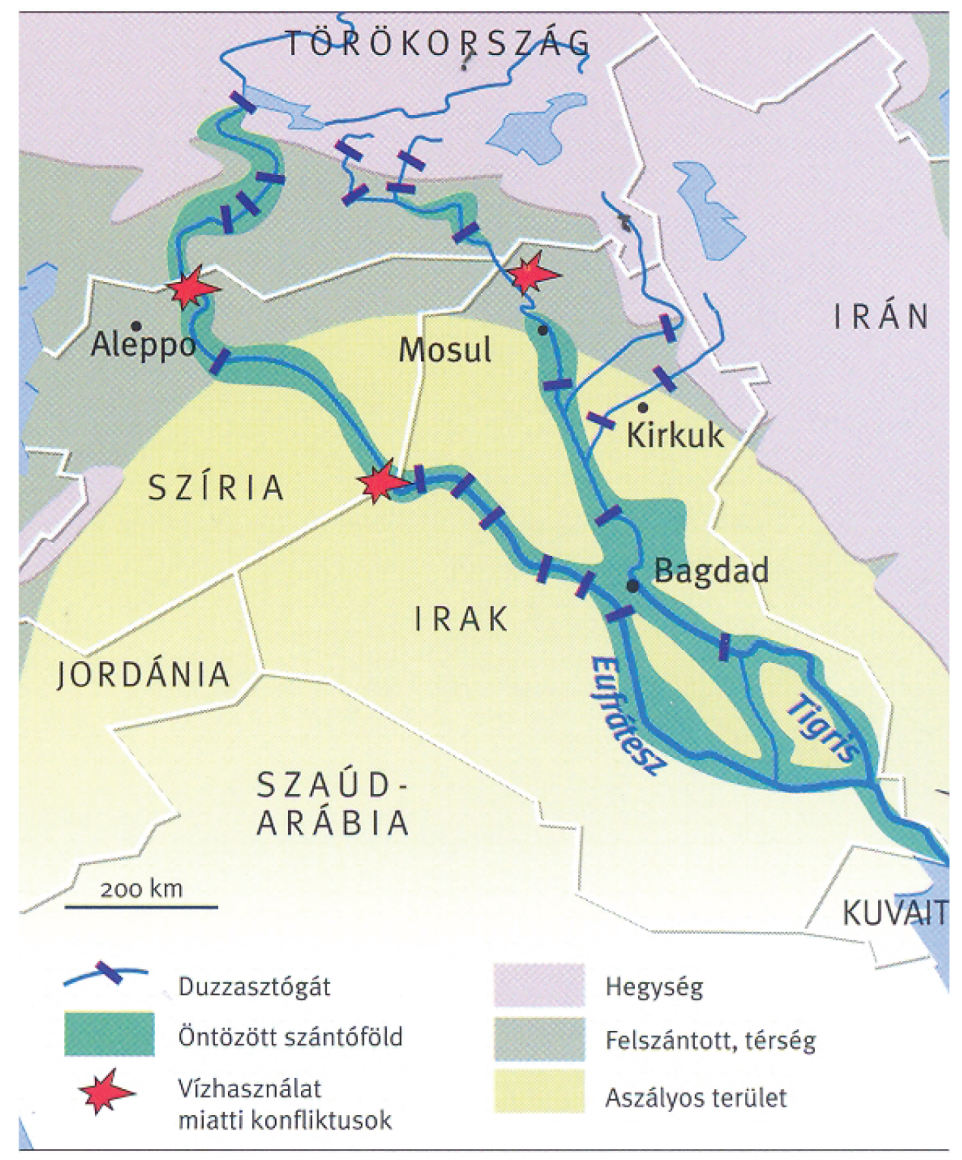

Map 1. Water resources in Middle East with Euphrates and Tiger rivers Knowledge in English: 1. column: Water dams, irrigated areas, conflicts for water use. 2. column: Mountain, ploughed areas, drought areas, Source: Larusse, Budapest, 2012 


\section{In Syria}

There are 141 dams in Syria with a total storage capacity of 15,8 $\mathrm{km}^{3}$. The largest dam is located at Al-Tabka on the Euphrates. It forms the Al-Assad lake with a storage capacity of $11,2 \mathrm{~km}^{3}$. The majority of these dams are located near Homs and Hama. Concerning the irrigation and drainage development, estimates on irrigation potential, based solely on soil resources, were about 5,9 million ha, which is roughly equal to the cultivable area. Considering the water resources available at present, irrigation potential is estimated at 1.250 .000 ha. Syria depends on international agreements with neighbouring countries on the sharing of river waters in the future (Haddad - Zsarnóczai, 2008).

The interior region plays considerable role for agricultural production. Surface irrigation is reported to be practiced on 981.273 ha. The predominant system of surface irrigation practiced is basin irrigation. Traditionally, irrigation in Syria has relied on flooding for cereals, furrow irrigation for vegetables and basin irrigation for fruit trees. Sprinkler irrigation is practiced on 30.000 ha, mostly in the Homs, Aleppo and Al-Hassakeh governorates. It has been developing on a wider scale recently, mainly because of groundwater scarcity, which has encouraged farmers to develop water-saving techniques, and because of equipment becoming available on the local market. Microirrigation is practiced on 2.000 ha. Earlier in 1993 it was estimated that $60,2 \%$ of the area was irrigated from groundwater and 39,8 $\%$ from surface water (gravity-fed or pumped from the rivers and lakes). The increase in irrigation from groundwater is the large number of farmers with small farm holdings. The latest available data estimate that over $75 \%$ of the farmers have holdings of less than 10 ha. On average, it is estimated that a household has 3,5 ha of irrigated land. Since most private farmers want secure and independent access to a supply of water. (Ministry of Agriculture and Agrarian Reform, 2005, see the Map).

Of the total area of 1.013.273 ha equipped for irrigation, 349.820 ha are involved in government irrigation projects and $78 \%$ of this land is also equipped for drainage. It is estimated that 105.000 ha of these government irrigated areas need rehabilitation. The irrigated area produces over $50 \%$ of the total agricultural production on about $18,6 \%$ of the cultivated land. Irrigated agricultural areas have already been seriously reduced in the Damascus basin in recent decades (see Chart 2).

Chart 2. Government's projects in Syria in 2000s

Source: UNDP/FAO (2005): Improved management of water resources for agricultural use (phase II). SYR/90/001. Damascus, Syria.

\begin{tabular}{|l||c||c|c||}
\hline \hline Size & Criteria & Total area in ha & as \% of total \\
\hline Large & $>20000$ ha & 257860 & 74 \\
\hline Medium & & 47840 & 14 \\
\hline \hline Small & $<2000$ ha & 44220 & 12 \\
\hline \hline Total & & 349820 & 100 \\
\hline
\end{tabular}

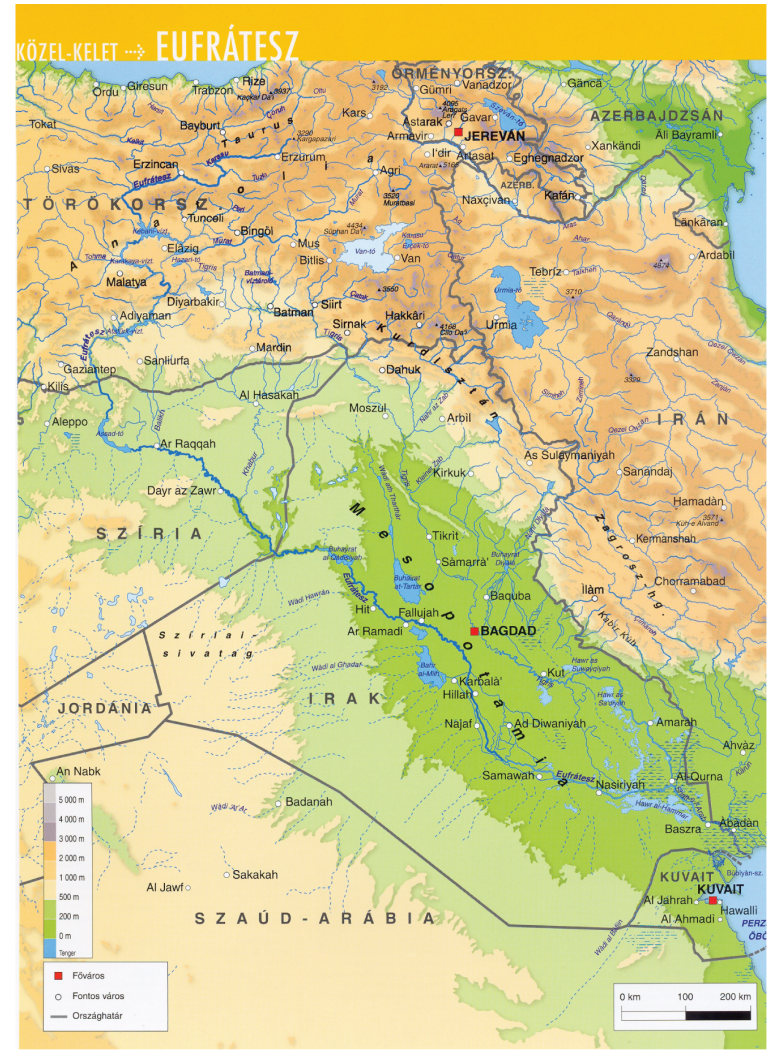

Map 2. Water resources in geographical map of Middle East Source: Larusse, Budapest, 2012 
The Government projects extended on 349.820 hectare area, which includes large, medium and small scale farms. The small scale government project is under 2000 hectare, but large scale project over 20.000 hectare areas. The Syrian Government wants to ensure the food supply for sharply increasing population based on established governmental agricultural projects, as state-owned farms. There is a wide variation in cropping patterns in the irrigated areas, depending on the water resources available and the agro-climatologically conditions. Strategic crops such as wheat and cotton are concentrated in the northern and eastern part of the country. More than $50 \%$ of the wheat and cotton produced comes from the Al-Hassakeh governorate, in the north-eastern part of the country. (UNDP/FAO, 2005; see Table-2). Preparing inventories of technologies, knowledge, know-how and practices, also traditional and modern technologies should be used for implementing modernization for irrigation system. The sustainable agriculture means to remain highly developed agricultural production level to supply foods. Promote national and multinational cooperation to realize main aims against effects of drought (Stekauerová Vlasta - Nagy: 2006, 289. p.).

According to the FAO guidelines on water quality for irrigation a severe restriction for irrigation is indicated when the electrical conductivity of the water exceeds $3 \mathrm{ds} / \mathrm{m}$. Water samples from three wells north of Deir el-zor within the steppe area have been analyzed. The EC values were ranging between 7 and $10 \mathrm{ds} / \mathrm{m}$. Furthermore the guidelines also indicated limits for specific ion toxity. In the analyzed samples sodium and chloride are found to be the dominant cations and anions respectively. A severe restriction degree is given in the guidelines when the concentration exceeds $9 \mathrm{meq} / 1$ for sodium and $10 \mathrm{meq} / 1$ for chloride. This concentration and the composition of these salts are considered the analyzed samples and similar waters are not suitable for irrigation (FAO-MAAR, 2001).

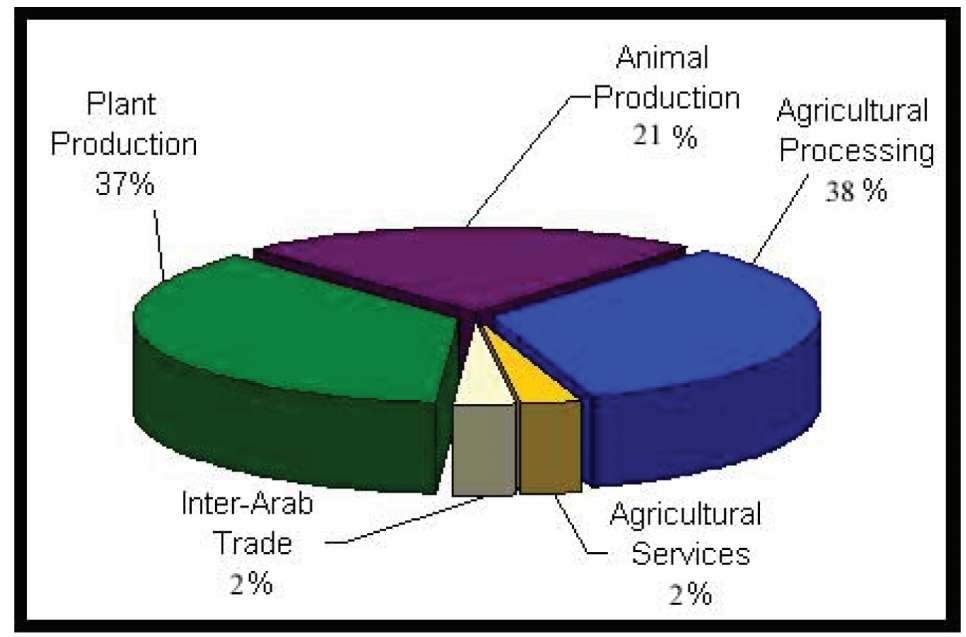

Figure 1. AAAID has sector distribution of this organization's costs and investments Source: Annual Report of AAAID, Khartum, 2008

The Geograhical Distribution of AAAID Investments in Member States

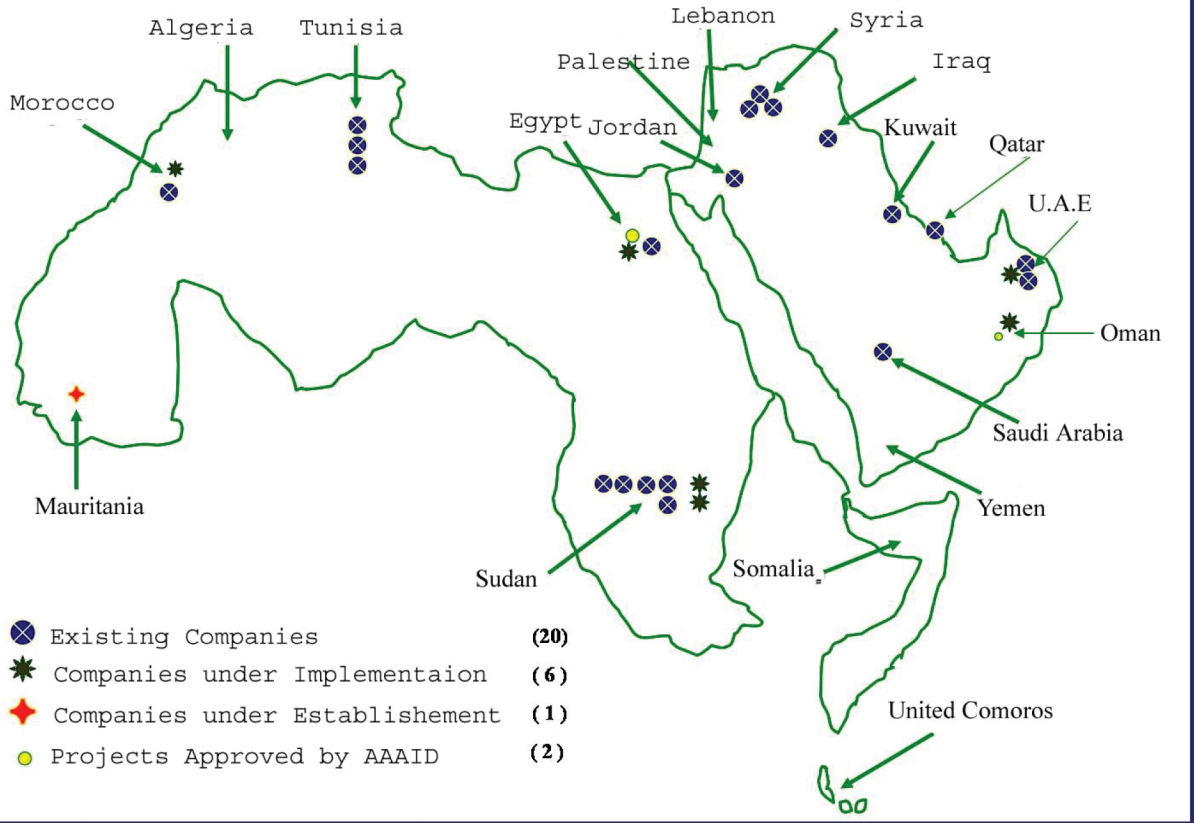

Figure 2. Distribution of Projects and Companies among Member States of AAAID Source: Annual Report of AAAID, Khartum, 2008 
Additionally to the irrigation and agricultural development at national level the international Arab organization like the Arab Authority for Agricultural Investment and Development (AAAID) wants to strengthen the cooperation among Arab countries, as member states of this organization in field of agricultural and food industry development. This AAAID is a regional financial and investment institution established in 1977, which has its centre in Khartum, in Sudan. The AAAID has been established and extended by 18 member countries, which are as follows: Saudi Arabia, Kuwait, Sudan, Iraq, United Arab Emirates, Qatar, Egypt, Algeria, Morocco, Mauritania, Somalia, Syria, Tunisia, Oman, Jordan, Lebanon, and State of Palestine, Yemen. At the beginning the Capital of this organization was as the total Authorized Capital of AAAID as 150 million Kuwaiti dinars (approximately 495,0 million US Dollars).

At present AAAID focuses on to invest projects increasing comparative advantageous for the production of food and agricultural products, for example cereals, specially wheat; vegetable oil, specially sunflower, sesame, peanut, cotton seed, olive oils; forages, specially alfalfa(jet), sorghum, and barley; sugar; milk and milk products, poultry, fish. Also the AAAID gives priority for agricultural inputs, specially fertilizers, veterinary medicines and machines (see the Figure: sector distribution of this organization's costs and investments).

\section{Conclusions}

1. The possible development trend of the technology and techniques can be solved by improving the renewable natural resource use from water, wind and solar energy within the sustainable investment; also we do not forget the salinization of sea water to make it be satisfactory drinking for population of these regions. As Fogarassy et al, (2014a, on p. 1.) declared about the difficulties about calculating in advance the positive and negative long-term impacts of a sustainable investment, or a development venture. Then they declared how serious global problems arising from the fact that numerous environmentalprotection oriented private and government ventures are implemented in an incorrect manner significantly impair the conditions of both the environment and the economy (market). There is a high number of innovative energy related investments, waste and water management projects, etc. in Europe, which cause more harmful effects then was earlier. Naturally it is true as above mentioned authors have right, that the innovative investments are needed for creating sustainable investment based on the environmental technology. But the MENA regions' countries have capital lack economies; even mostly the oil-crude exporting countries have this one, which obstacles their developing transfer technology in direction environment friendly one within as sustainable investments.

Naturally countries of MENA region should increase advanced technology of food manufacturing industry in order to increase highly value added of food products for export based on the comparative advantageous of these products. Also the highly level of irrigation investment cost can increase the domestic consumption prices of food products, in spite that the farmers do not pay fee for water-use. The agricultural development strategy including irrigation system network build up needs to increase qualitative level of agricultural and food products.

The developed farm management conception can be capable for sustaining agriculture based on projects to be achieved successfully by using foreign expertise and managers in these projects for applying high-tech production methods.

The Small-scale Irrigation Sub-System cannot adapt advanced irrigation technologies with rivers and water channels. This irrigation system extends in small perennial streams, in oasis or areas belonging to flood of river water. This irrigation system can successfully base in case of cereals, fodder, vegetables and fruits.

2. Fogarassy et al (2014b, on p. 3228) focus on the importance on the decision makers, who must take the prevention of environmental problems, and other economic problems into consideration, which can surface due to the cessation of various products and processes. Without including the benefits and setbacks of these consequences, there can be no decision (Fogarassy et al, 2014 b; on p. 3228). From this point of view the prevent needs technology developed based on the environment friendly.

Syria and Libya both of countries are depend from food import, and food export compulsion for re-paying foreign-credit, very strong demand for foreign technical equipment, lack of experts, farmers are not experienced. Not considerable use water is for energy resource, as renewable one. But in Libya there were more favourable supply capital resources, less population, almost dessert area, $1 \%$ of and is irrigated, drought weather all of the year, salinization process more in the cost area.

In Syria the lack of capital, favourable cultivable land, more longer period of reining in a year, less occurs for appearing salt in continental areas are closed to cost, wider side dam net-work with more natural water supply, which elements characterize the agricultural sector and the irrigation possibility.

3. According to the natural and geographical conditions in the MENA regions the volume of soil water is so much different, for example it is not significant in Egypt and some countries of the Arabian Peninsula. The soil water cannot play significant role of MENA region, it can be important to discover groundwater storage, which can ensure water resource for irrigation. In some countries of the MENA regions the soil water contributes to less than 20 per cent of the national water use, for example in case of Jordan. In the other MENA countries, for example Turkey, Syria and Iran, which do not have considerable soil water during almost year, but rainfall can provide soil water for winter season, which can ensure some of water resources for dry-land farming and grazing. The soil water considerably contributes to increase agricultural yield and food supply for population of this part of MENA region (FAO, No.33).

4. Because the costs were so difficultly established and because much of the desalination activity is concentrated in economies that operate in a privileged world of oil enrichment it is not easy to provide reliable opportunity costs or definitive predictions of what the costs will be in the future (FAO, No. 33). The re-use of water has played a major role in the use and management of water in areas where topographic circumstances allowed water to drain from irrigated fields to those located at lower levels further down the system. According to the international estimations the national level Egyptian water utilization in agriculture, through re-use, is about over 70 per cent.

Also there are some main components in investment projects, which are as follows: $1 /$ the construction of a water treatment plant; 2 / rehabilitation of a large pipeline; 3 / construction of high capacity reservoirs.

5. As Fogarassy et al (2014c, on p. 33) focus on the importance of the "transition thinking”, which is a normative and practice oriented approach on sustainability development. Naturally the leaders of countries in MENA regions also have to follow this sustainable approach in order they can improve environment friendly technology. They authors have right to implement the knowledge of different fields of science, extended with practice experience. (Fogarassy et al, 2014c, on p. 33).

\section{References}

[1] FAO (No.33): Yield response to water. Irrigation and Drainage Paper, Rome 
[2] FAO-MAAR (2001). "The Utilization of Water Resources for Agriculture in Syria". FAO

Report GCP/SYR/006/ITA.

[3] Fogarassy Cs, Bakosné Böröcz M, Molnár S (2014a): Process of sustainable project development with Rubik's Cube using Game Theory interpretations. International Journal of Advanced and Innovative Research, 3: (10) pp. 1-6.

http://ijair.jctjournals.com/

[4] Fogarassy Cs, Bakosné Böröcz M, Molnár S (2014b): Sustainability Relations for Innovation, Low-Carbon Principles for "Rubik's Cube" Solution, International Journal on Recent and Innovation Trends in Computing and Communication 2: (10) pp. 3226-3232

http://www.ijritcc.org/

[5] Fogarassy Cs, Szarka K, Lehota J (2014c): The „transition thinking" and 50plus generation thoughts of sustainability in different countries (case study in Hungary and Switzerland), International Journal of Advanced Research in Management and Social Sciences (ISSN: 2278-6236) Volume 3, Issue 11, November 2014 pp. 33-48 http://www.garph.co.uk/index.html

[6] Haddad G., Zsarnóczai J. S. (2008): Geographical background for agriculture in Syria. (A mezőgazdaság földrajzi háttere Szíriában).

VII. Alps-Adria Scientific Workshop on Soil-Plant Interrelations, Session: Land Use II., Stara Lesna, Slovakia, 28 April - 2 May, 2008. Edited by Hidvégi, Szilvia. Volume 36, Supplement 2008. Akadémia Kiadó. Pp. 1019-1022. (XXII.), Abstract p. 1019, ISSN 0546-8191

[7] Huda Fathi Salem, Villányi L., Karim K, Zsarnóczai J. S. (2005): The Great Man-Made River Project and Its Importance in Libya. (Az ember alkotta nagy folyó beruházás és ennek fontossága Líbiában). Bulletin of the Szent István University, Gödöllő, pp. 227- 236., Abstract p. 227. ISSN 1586-4502

[8] Ligetvári F, Várallyay Gy, Schweitzer F.(2006): Sivatagok és az elsivatagosodás nemzetközi éve, UNESCO 2006. Agrokémia és Talajtan, Vol. 55. No. 2 pp 487-498.

[9] Ministry of Agriculture and Agrarian Reform (2005): Report: Balance of land utilization for 2005. Damascus, Syria

[10] Norman M J T, Pearson C J, Searle P G E, (1995): The ecology of tropical food crops. Cambridge University Press, UK, p. 430. ISBN 0521422647

[11] Pallas, P. (1980) Water resources of the Socialist People's Libyan Arab Jamahiriya. In: The Geology of Libya. Proceedings of the Second Symposium on the Geology of Libya. Academic Press, London.

[12] Stekauerová Vlasta, Nagy V. (2006): Course of soil layer water content in agricultural cultivated soil during years 1999 and 2000. Cereal Research Communications, pp. 287-290.

[13] The Large Farm Project in Al-Khadra Area (2004). The Great Man-Made River Project, Socialist People Libyan Arab Jamahirija (SPLAJ = Libya), p. 23.

[14] Yahia Ali Mughram, Zsarnóczai J. S. (2008): Irrigation Possibility in Middle East and North Africa. (Öntözési lehetőségek a Közel-Keleten és Észak-Afrikában).

VII. Alps-Adria Scientific Workshop on Soil-Plant Interrelations, Session: Land Use II., Stara Lesna, Slovakia, 28 April - 2 May, 2008. Edited by Hidvégi, Szilvia. Volume 36, Supplement 2008. Akadémia Kiadó. Pp. 2083-2086. (XLIV.) ISSN 0546-8191

[15] UNDP/FAO (2005): Improved management of water resources for agricultural use (phase II). SYR/90/001. Damascus, Syria. 